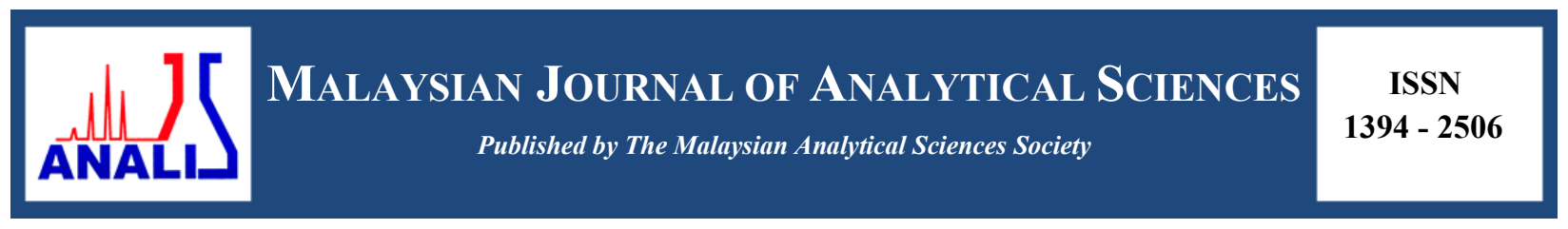

\title{
THE ELECTROCHEMICAL BEHAVIOR OF ZINC OXIDE/REDUCED GRAPHENE OXIDE COMPOSITE ELECTRODE IN DOPAMINE
}

\author{
(Sifat Elektrokimia Elektrod Komposit Zink Oksida/Grafin Oksida Terturun dalam Dopamin) \\ Farhanini Yusoff ${ }^{*}$, Ngai Tze Khing ${ }^{1}$, Chai Chee Hao ${ }^{1}$, Lee Pak Sang ${ }^{1}$, Nurul'ain Basyirah Muhamad ${ }^{1}$, \\ Noorashikin Md Saleh ${ }^{2}$ \\ ${ }^{1}$ School of Marine and Environmental Sciences, \\ Universiti Malaysia Terengganu, 21030 Kuala Nerus, Terengganu, Malaysia \\ ${ }^{2}$ Research Centre for Sustainable Process Technology, \\ Department of Chemical Engineering, Faculty of Engineering and Built Environment, \\ Universiti Kebangsaan Malaysia, 43600 UKM Bangi, Selangor, Malaysia \\ *Corresponding author: farhanini@umt.edu.my
}

Received: 2 January 2018; Accepted: 6 March 2018

\begin{abstract}
Zinc oxide/reduced graphene oxide $(\mathrm{ZnO} / \mathrm{rGO})$ composite was synthesized via the modified Hummers' method. The presence of $\mathrm{ZnO}$ composite on the rGO sheets was confirmed by Scanning Electron Microscope (SEM), X-Ray Diffractometer (XRD) and Fourier Transform Infrared (FTIR) spectrometer. FTIR result showed the formation of $\mathrm{ZnO} / \mathrm{rGO}$ with the presence $\mathrm{ZnO}$ stretching peak and the surface of $\mathrm{ZnO} / \mathrm{rGO}$ was found to have better morphology with functionalized groups attached to it. XRD analysis also confirms the formation of $\mathrm{ZnO} / \mathrm{rGO}$ composite by wurtzite structured indexed peak of the diffractogram. The $\mathrm{ZnO} / \mathrm{rGO}$ composite was drop on the surface of GCE by drop casting method to increase the electrocatalytic activities of bare GCE. The electrochemical behaviour of $\mathrm{ZnO} / \mathrm{rGO}$ modified electrode shows the enhancement in electron transfer and the system is diffusion-controlled. The electrochemical studies also revealed that the $\mathrm{ZnO} / \mathrm{rGO} / \mathrm{GCE}$ dramatically increased the current response against the dopamine (DA), due to the synergistic effect emerged between $\mathrm{ZnO}$ and rGO. This attributed that $\mathrm{ZnO} / \mathrm{rGO} / \mathrm{GCE}$ could exhibit excellent electrocatalytic activity and effective electron transfer kinetics towards the oxidation of DA. Therefore, the $\mathrm{ZnO} / \mathrm{rGO} / \mathrm{GCE}$ could be used to determine the DA concentration and provide an ideal matrix for clinical applications.
\end{abstract}

Keywords: zinc oxide, reduced graphene oxide, composite materials, dopamine, electrocatalysis

Abstrak

Komposit zink oksida/grafin oksida terturun ( $\mathrm{ZnO} / \mathrm{rGO})$ telah disintesis melalui kaedah Hummer terubahsuai. Kehadiran komposit $\mathrm{ZnO}$ pada lapisan rGO telah diujikan oleh mikroskop imbasan elektron (SEM), Pembelauan sinar X (XRD) dan Inframerah transformasi Fourier (FTIR). Keputusan FTIR menunjukkan pembentukan ZnO/rGO dengan kehadiran puncak ZnO dan permukaan $\mathrm{ZnO} / \mathrm{rGO}$ didapati mempunyai morfologi yang lebih baik dengan kumpulan berfungsi melekat padanya. Analisis XRD juga menunjukkan pembentukan komposit $\mathrm{ZnO} / \mathrm{rGO}$ melalui diffraktogram indeks puncak struktrur wurtzit. Komposit $\mathrm{ZnO} / \mathrm{rGO}$ telah diubahsuai dengan elektrod karbon berkaca (GCE) dengan menggunakan kaedah alas titis. Perlakuan elektrokimia $\mathrm{ZnO} / \mathrm{rGO} / \mathrm{GCE}$ menunjukkan peningkatan dalam pemindahan elektron dan sistem adalah proses serapan terkawal. Kajian elektrokimia mendedahkan bahawa respon arus $\mathrm{ZnO} / \mathrm{rGO} / \mathrm{GCE}$ meningkat terhadap DA, disebabkan kesan sinergi antara $\mathrm{ZnO}$ dan rGO. Ini disebabkan respon arus $\mathrm{ZnO} / \mathrm{rGO} / \mathrm{GCE}$ boleh mempamerkan aktiviti elektropemangkin yang berkesan terhadap kinetik pemindahan elektron DA. Oleh itu, $\mathrm{ZnO} / \mathrm{rGO} / \mathrm{GCE}$ boleh digunakan untuk menentukan kepekatan DA dan menjadi pemangkin sesuai untuk aplikasi klinikal.

Kata kunci: zink oksida, grafin oksida terturun, bahan komposit, dopamin, elektropemangkin 


\section{Introduction}

Dopamine (DA) is the most significant catecholamines, belongs to the excitatory neurotransmitter family which consists of an amine group linked to a catechol structure. It has great influence on central nervous, endocrine, and cardiovascular system [1]. Moreover, DA plays a vital role in brain pleasure centers, emotional response and help to regulate movement for human. Abnormal level of dopamine in human body can lead to central nervous system disorders such as Parkinson's, Alzheimer's, Huntington's disease and schizophrenia diseases are cause by. Recent studies show that low dopaminergic activity, as indicated by high DA/metabolite ratios, was positively correlated with addiction [2]. Therefore, the development of an accurate and sensitive method for DA determination is necessary for the clinical diagnostic purposes.

Numerous analytical techniques are available for the detection of DA level such as UV-vis spectrometry, capillary electrophoresis, chemiluminescence and electrochemical analysis. Among these methods, electrochemical method are favorable owing to their advantages such fast speed, low cost, low detection limits and also high in accuracy [3]. However, uric acid (UA) and ascorbic acid (AA) are usually coexisted with DA in the extracellular fluids of the central nervous system in mammals or the biological fluid such as urine, blood and human breast milk [4]. Thus, AA and UA will become the interfering species that will result in poor selectivity and sensitivity towards DA detection.

In order to overcome this problem, two fundamental approaches were often performed; improve the electrocatalytic performance on the electrode surface to separate their oxidation potentials, and selective interaction with DA on the electrode surface without interferences [5]. From the strategies, various chemically modified electrodes have been fabricated using polymers [6], metal oxides [7], nanoparticles [8], and carbon based materials [9]. A great deal of attention has been given to the use of multiwall carbon nanotubes (MWNTs), and more recently to graphene, as modification materials on the surface of electrodes [10].

Graphene, a two-dimensional sheet of $\mathrm{sp}^{2}$-hybridized carbon, has receive a lot of attention in the electrochemical field due to its unexpected stability, exotic band structure and unique electronic properties, especially the high specific surface area and excellent electric conductivity low mass density. Graphene was obtained so far by several techniques including mechanical exfoliation of graphite [11], chemical vapor deposition [12], electrochemical reduction of exfoliated graphite oxide precursor [13] and chemical reduction of graphene oxide [14]. Among the various methods reported for reduction of GO, the chemical reduction of GO sheets pre-deposited on electrode surfaces seems to be a promising route for preparing reduced graphene oxide (rGO)-modified electrode surfaces because it is simple, high surface to volume ratio, abundant defect sites, and fast electron transfer rate [15]. One major drawback of rGO is the natural tendency of agglomeration and restacking due to van der Waals interactions, which lower the surface area of product [16]. To overcome this problem, modification of rGO with different functional molecules would have to be introduced to improve their electrochemical activity. Studies have shown that fabricating metal/metal oxide-nanocarbon hybrid have increased the catalysts properties by utilizing both the advantages of metal and nanocarbon $[17,18]$.

In this research, the zinc oxide/reduced graphene oxide composite ( $\mathrm{ZnO} / \mathrm{rGO})$ electrode has been developed to investigate its performance towards oxidation of DA. It was then used to determine the concentration of DA in human urine samples.

\section{Chemicals and Materials}

\section{Materials and Methods}

3-hydroxytyramine hydrochloride (DA), natural graphite powder, concentrated sulfuric acid $\left(\mathrm{H}_{2} \mathrm{SO}_{4}, 95-98 \%\right)$, hydrochloric acid $(\mathrm{HCl})$, sodium nitrite $\left(\mathrm{NaNO}_{3}\right)$, potassium permanganate $\left(\mathrm{KMnO}_{4}\right)$, hydrogen peroxide $\left(\mathrm{H}_{2} \mathrm{O}_{2}\right.$, $30 \%)$, zinc nitrate $\left(\mathrm{Zn}\left(\mathrm{NO}_{3}\right)_{2}\right)$, potassium hydroxide $(\mathrm{KOH})$, potassium ferrocyanide $\left(\left[\mathrm{Fe}(\mathrm{CN})_{6}\right]^{4-}\right)$, potassium chloride $(\mathrm{KCl})$, disodium hydrogen phosphate dodecahydrate $\left(\mathrm{Na}_{2} \mathrm{HPO}_{4} \bullet 12 \mathrm{H}_{2} \mathrm{O}\right)$, and sodium dihydrogen phosphate dehydrate $\left(\mathrm{NaH}_{2} \mathrm{PO}_{4} \cdot 2 \mathrm{H}_{2} \mathrm{O}\right)$ were purchased from Sigma Aldrich, USA. The stock solution of DA was prepared in the $0.1 \mathrm{M}$ of phosphate buffer solution. All reagents are of analytical grade and were used without any further purification. 


\section{Instrumentation}

The electrochemical experiment was performed using Potentiostat/Galvanostat module PGSTAT30 (Metrohm AUTOLAB, Nertherlands), three electrode systems consist of platinum wire counter electrode, glassy carbon electrode (BASi MF-2012 $3.0 \mathrm{~mm}$ diameter), with or without modification of $\mathrm{ZnO}$-decorated $\mathrm{rGO}$ as working electrode, and $\mathrm{Ag} / \mathrm{AgCl}$ (Methrom, with $3 \mathrm{M}$ of $\mathrm{KCl}$ ) as reference electrode. Physical characterization of $\mathrm{ZnO} / \mathrm{rGO}$ were performed using Scanning electron microscope (SEM, JEOL JSM-6360LA), X-Ray Diffractometer (XRD, Rigaku MiniFlex II), and Fourier Transform Infrared Spectrometer (FTIR, PerkinElmer Spectrum 100).

\section{Preparation of $\mathrm{ZnO} / \mathrm{rGO}$}

The GO which synthesized from the graphite powder via the modified Hummers method [19] was reduced to reduced graphene oxide ( $\mathrm{rGO}$ ) by zinc nitrate as reduced precursors. Firstly, $0.01 \mathrm{~mol}$ of $\mathrm{Zn}\left(\mathrm{NO}_{3}\right)_{2}$ and $50 \mathrm{~mL}$ of distilled water were added to the conical flask and stirred vigorously with magnetic bar in the ice water bath for 1 hours. Next, $0.0904 \mathrm{~g}$ of GO was treated with $100 \mathrm{~mL}$ of distilled water to form GO solution. The GO solution was separated in to two centrifuge tubes $(50 \mathrm{~mL})$ with equal amount and ultrasonic for 1 hours. After 1 hours, the GO solution was added to the of $\mathrm{Zn}\left(\mathrm{NO}_{3}\right)_{2}$ mixture solution and stirred homogenously for 10 minutes. Then, $5.6 \mathrm{~g}$ of potassium hydroxide was added to the mixture solution and left for overnight. In this time, the $\mathrm{pH}$ for mixture solution is $\mathrm{pH}$ 8.5. After that, the mixture solution was centrifuged and filter by suction filtration. The distilled water was added during the filtration process to neutralize the $\mathrm{rGO}$ to $\mathrm{pH}$ 7. The $\mathrm{rGO}$ was dried at oven for 1 hour to obtain the $\mathrm{ZnO} / \mathrm{rGO}$ precursors.

\section{Fabrication of $\mathrm{ZnO} / \mathrm{rGO} / \mathrm{GCE}$}

The working electrode was prepared by dropping the $\mathrm{ZnO} / \mathrm{rGO}$ solution onto a glassy carbon electrode. First, glassy carbon electrode (GCE) was polished by alumina oxide followed by rinsing with water, ethanol and water, in turn. To modify the $\mathrm{ZnO} / \mathrm{rGO} / \mathrm{GCE}, 1 \mathrm{mg} \mathrm{ZnO} / \mathrm{rGO}$ powder was ultrasonic dispersed into $10 \mathrm{~mL}$ of distilled water for 20 minutes. Then, $8 \mu \mathrm{L}$ of $\mathrm{ZnO} / \mathrm{rGO}$ was dropped onto a clean $\mathrm{GCE}$ with a micropipette and dried at room temperature. The electrocatalytic ability of the $\mathrm{ZnO} / \mathrm{rGO}$ modified electrode was investigated by cyclic voltammetry in $0.1 \mathrm{M}$ of phosphate buffer solution ( $\mathrm{pH} 7.0)$ as electrolyte.

\section{Electrochemical characterization $\mathrm{ZnO} / \mathrm{rGO} / \mathrm{GCE}$}

The cyclic voltammetry of $5.0 \mathrm{mM} \mathrm{K}_{3}\left[\mathrm{Fe}(\mathrm{CN})^{6}\right]$ in $0.1 \mathrm{M} \mathrm{KCl}$ on all electrodes were carried out at potential window of -0.2 to $0.8 \mathrm{~V}$ at room temperature with different scan rates using an electrochemical cell with three electrodes system. The electrolyte solution was purged with nitrogen gas to eliminate oxygen before use.

\section{Results and Discussion}

\section{Characterization of ZnO/rGO: Fourier transform infrared (FTIR) analysis}

FT-IR spectroscopy is known to be an important tool to characterize the graphene-based hybrid materials. In the FTIR spectra of the pure graphite powder (Figure 1a), there is no significant peak observed in raw graphite. This attributed to that the graphite powder was pure and do not contain any functional groups on the graphite molecules. In the FT-IR spectra of GO samples (Figure 1b), there is a strong broad peak presence at $3390 \mathrm{~cm}^{-1}$ and several weak ones at 1728, 1622 and $1053 \mathrm{~cm}^{-1}$, which are attributed to the stretching vibration of $\mathrm{O}-\mathrm{H}$ groups (carboxyl and hydroxyl), stretching of $\mathrm{C}=\mathrm{O}$, skeletal vibration of $\mathrm{C}=\mathrm{C}$ (carboxyl or carbonyl), and stretching vibrations of $\mathrm{C}$ $\mathrm{O}$ (epoxy or alkoxy), respectively.

The strong characteristics of $\mathrm{C}=\mathrm{O}$ stretch at $1728 \mathrm{~cm}^{-1}$ indicating the present of oxygen-containing group in GO surface. After the GO is chemically reduced, the spectrum (Figure 1c) resulted in significant reduction of hydroxyl, carbonyl, and epoxide group. The $\mathrm{C}=\mathrm{O}$ vibration band which located at $1728 \mathrm{~cm}^{-1}$ was disappeared, while the board $\mathrm{O}-\mathrm{H}, \mathrm{C}=\mathrm{C}$ and $\mathrm{C}-\mathrm{O}$ stretching bands remain. These results demonstrate that the functional oxygen-containing group on the GO surface were almost reduced after the reduction by $\mathrm{Zn}\left(\mathrm{NO}_{3}\right)_{2}$. Additionally, the spectrum for $\mathrm{ZnO} / \mathrm{rGO}$ showed the distinct peak at around $507 \mathrm{~cm}^{-1}$, which corresponds to $\mathrm{ZnO}$ [20]. Based on the analysis, one can conclude that $\mathrm{GO}$ was both reduced and functionalized by $\mathrm{Zn}\left(\mathrm{NO}_{3}\right)_{2}$. 


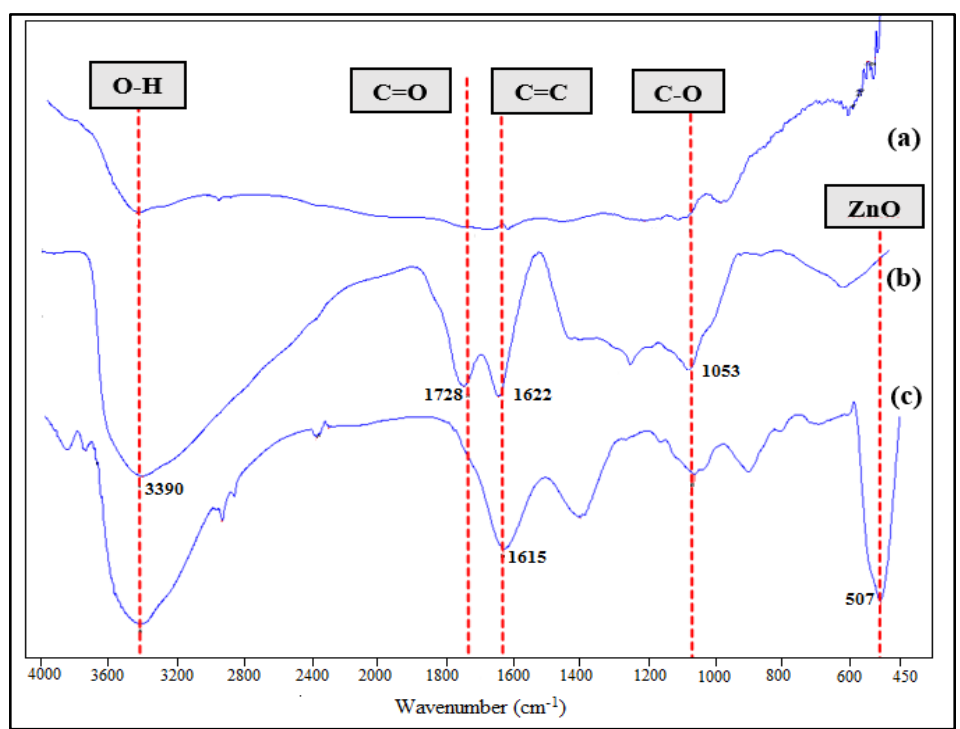

Figure 1. FT-IR Spectra of (a) Graphite, (b) GO, and (c) $\mathrm{ZnO} / \mathrm{rGO}$

Consequently, the purpose for reduction of GO was to eliminated the epoxy and hydroxyl groups on the plane, while other functional groups, such as carboxyl, carbonyl and ester groups which present at the edges of the carbon plane only have a minor influence on the conductivity of an rGO sheet. Moreover, the strong sharp peak of $\mathrm{ZnO}$ shown in FTIR spectra indicated that the $\mathrm{ZnO}$ were anchoring on the surface of rGO layer. Therefore, the electrochemical properties of $\mathrm{ZnO} / \mathrm{rGO}$ composite is expected to enhance due to the wide band gap particles of $\mathrm{ZnO}$ and large surface area of graphene compared to those of pristine graphene oxide and $\mathrm{ZnO}$ particles alone.

\section{X-ray diffractometry analysis (XRD)}

The XRD analysis is used to verify the formation of the $\mathrm{ZnO}$ crystal on the surface of GO. The XRD pattern (Figure 2a) of graphite shows an intensive diffraction peak at $2 \theta=26.5^{\circ}$, reflecting the crystal form of graphite. If compare to GO spectra, the characteristic peak of GO at $10.25^{\circ}$ was observed that indicates the presence of the larger interlayer distance between GO due to the oxidation of graphite and formation of the functional groups such as carboxyl, hydroxyl and epoxy, as indicated in the FT-IR results. While in the XRD pattern of $\mathrm{ZnO} / \mathrm{rGO}$, there are 8 peaks appearing at $2 \theta$ values of $31.7,34.3,36.1,47.3,56.4,62.6,67.7$, and $68.8^{\circ}$ corresponding to the crystal planes of (100), (101), (102), (110), (103), (112), and (201) respectively. These peaks are indexed as wurtzite structured (crystal structure) of $\mathrm{ZnO}$, which are consistent to the value in the standard card. Theoretically (002) peak of rGO is expected to appear in the XRD diffractogram of $\mathrm{ZnO} / \mathrm{rGO}$. However, it cannot be observed in the corresponding compositions (Figure 2b), indicating that the surfaces of rGO are fully covered by $\mathrm{ZnO}$ [21]. Hence, the diffraction peaks are mainly from the up-layer $\mathrm{ZnO}$ phase in the $\mathrm{ZnO} / \mathrm{rGO}$ compositions. Moreover, the peak disappearance at $10.25^{\circ}$ also indicating the surface of rGO is fully covered by $\mathrm{ZnO}$. Therefore, it can be concluded that there is the formation of $\mathrm{ZnO} / \mathrm{rGO}$ after the $\mathrm{GO}$ was reduced by zinc nitrate. 


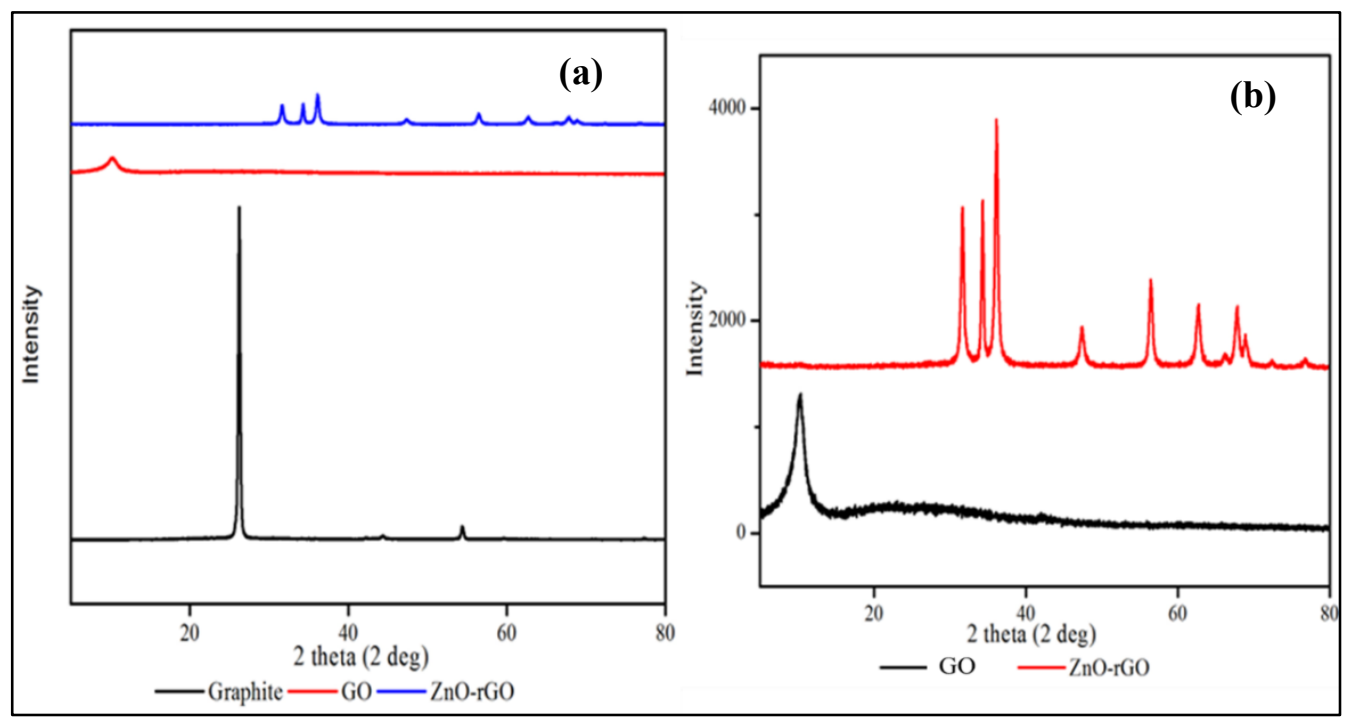

Figure 2. (a) $\mathrm{XRD}$ patterns for graphite, $\mathrm{GO}$ and $\mathrm{ZnO} / \mathrm{rGO}$ composite and (b) Enlarge $\mathrm{XRD}$ patterns for $\mathrm{GO}$ and $\mathrm{ZnO} / \mathrm{rGO}$ composite

\section{Scanning electron microscopy analysis (SEM)}

The morphology of the graphite, GO, and $\mathrm{ZnO} / \mathrm{rGO}$ (Figure 3) was physically characterized by SEM. From the SEM image of pure graphite, the individual needle shaped particles are made up of graphite having intrinsic flake morphology. Graphite arranged in agglomerates and presented a typical multilayer structure. The SEM image of GO showing that the oxidation of graphite after treated with modified Hummers' method caused a visible change in their morphology, or it has a wrinkled appearance with multiple folds. This wrinkled aspect can be explained by the oxidation process to promote the admission of hydroxyl groups and epoxy groups, known as functional groups [21].
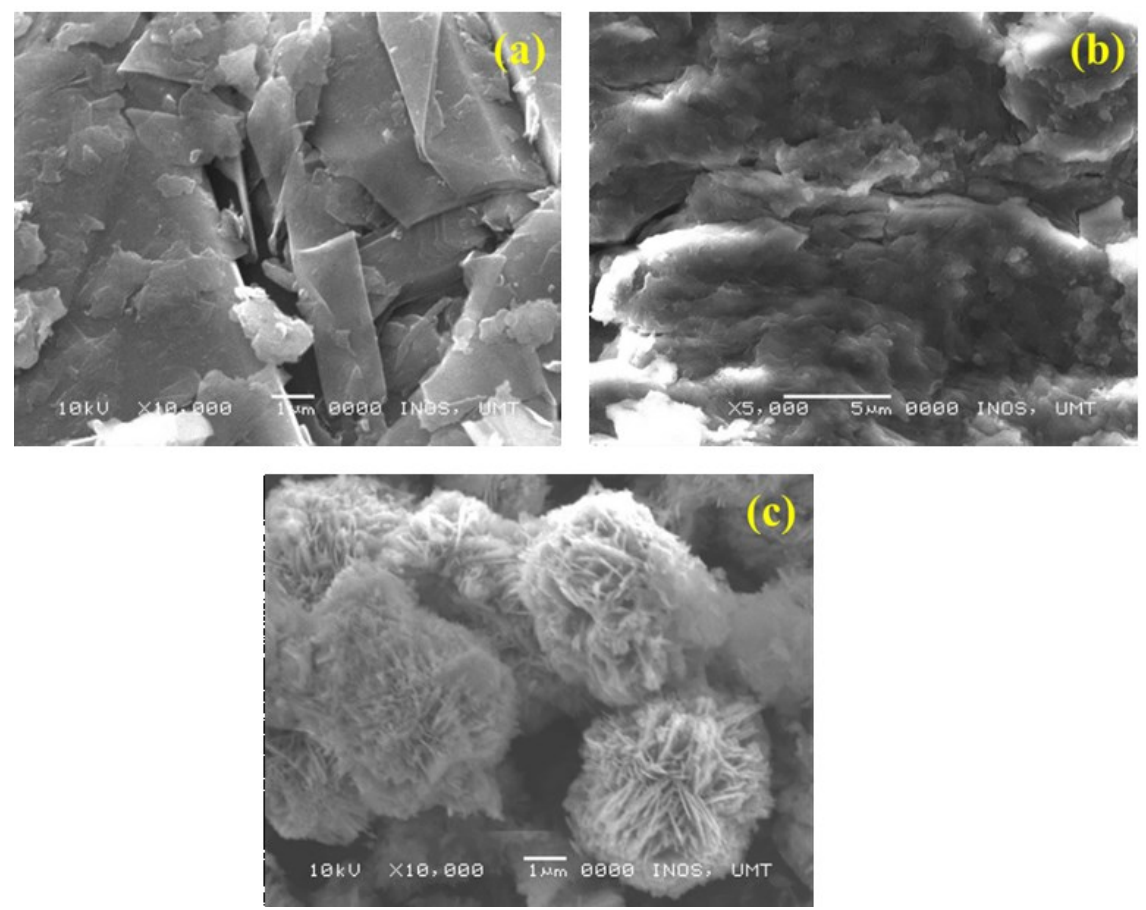

Figure 3. SEM image of (a) pure graphite; (b) $\mathrm{GO}$ and (c) $\mathrm{ZnO} / \mathrm{rGO}$ composite 
The formation of $\mathrm{ZnO}$ on the surface of graphene layer is indicated by the microsphere-like hierarchical structures after the GO is undergoes reduction by $\mathrm{Zn}\left(\mathrm{NO}_{3}\right)_{2}$. The $\mathrm{ZnO}$ composite with an average size of $5 \mu \mathrm{m}$ were horizontally and randomly stacked between or on the RGO layers, in other words, graphene sheets are homogeneously incorporated in a $\mathrm{ZnO}$ matrix which clearly shown in Figure 3c. This result is also supported by $\mathrm{XRD}$ analysis. It may be due to the restriction of full length extension of $\mathrm{ZnO}$ in the space within the graphene layers. The results also indicated that the functional groups in $\mathrm{GO}$ were significantly reduced during $\mathrm{Zn}\left(\mathrm{NO}_{3}\right)_{2}$ reduction.

\section{The electrochemical behavior of $\mathrm{ZnO} / \mathrm{rGO}$ modified electrode}

The electrochemical behavior of bare $\mathrm{GCE}, \mathrm{GO}$ and $\mathrm{ZnO} / \mathrm{rGO} / \mathrm{GCE}$ was investigated by cyclic voltammetry (Figure 4a). Cyclic voltammetry (CV) is frequently used in analytical field due to it offers a wealth of experimental information and insights into both the kinetic and thermodynamic details of many chemical systems. The electrochemical behavior of bare $\mathrm{GCE}$ and $\mathrm{ZnO} / \mathrm{rGO} / \mathrm{GCE}$ is investigated by $\mathrm{CV}$ to elucidate their electron transfer behavior in the presence of $0.1 \mathrm{M} \mathrm{KCl}$ and $0.05 \mathrm{M} \mathrm{K}_{4}\left[\mathrm{Fe}(\mathrm{CN})_{6}\right]$ at scan rate $50 \mathrm{mVs}^{-1}$ and potential range in $-0.2 \mathrm{~V}$ to $0.8 \mathrm{~V}$. Curve of the bare GCE and $\mathrm{ZnO} / \mathrm{rGO} / \mathrm{GCE}$ showed a pair of well-defined quasi-reversible peaks with the anodic and cathodic peaks for bare GCE is at $348 \mathrm{mV}$ and $200 \mathrm{mV}$, respectively. Meanwhile, the anodic and cathodic potential of $\mathrm{ZnO} / \mathrm{rGO} / \mathrm{GCE}$ are $298 \mathrm{mV}$ and $190 \mathrm{mV}$, respectively.

The voltammogram shows the oxidation peak on $\mathrm{ZnO} / \mathrm{rGO} / \mathrm{GCE}$ was negatively shifted to $298 \mathrm{mV}$ with remarkably enhanced of oxidation peak current. The $\mathrm{ZnO} / \mathrm{rGO} / \mathrm{GCE}$ present the largest background current and the peak current compared with the bare electrode. For the modified electrode $(\mathrm{ZnO} / \mathrm{rGO} / \mathrm{GCE})$, the oxidation peak current was dramatically enhanced to $0.32 \mathrm{~mA}$ compare to GO and bare GCE. The decreased in peak potential separation $\left(\Delta \mathrm{E}_{\mathrm{p}}\right.$ $\left.=\mathrm{E}_{\text {Anodic Peak }}-\mathrm{E}_{\text {Cathodic peak }}\right)$ are observed for $\mathrm{ZnO} / \mathrm{rGO} / \mathrm{GCE}\left(\Delta \mathrm{E}_{\mathrm{p}}=99.8 \mathrm{mV}\right)$ than that on $\mathrm{GO}$ and bare GCE electrode $\left(\Delta \mathrm{E}_{\mathrm{p}}=150 \mathrm{mV}\right)$.
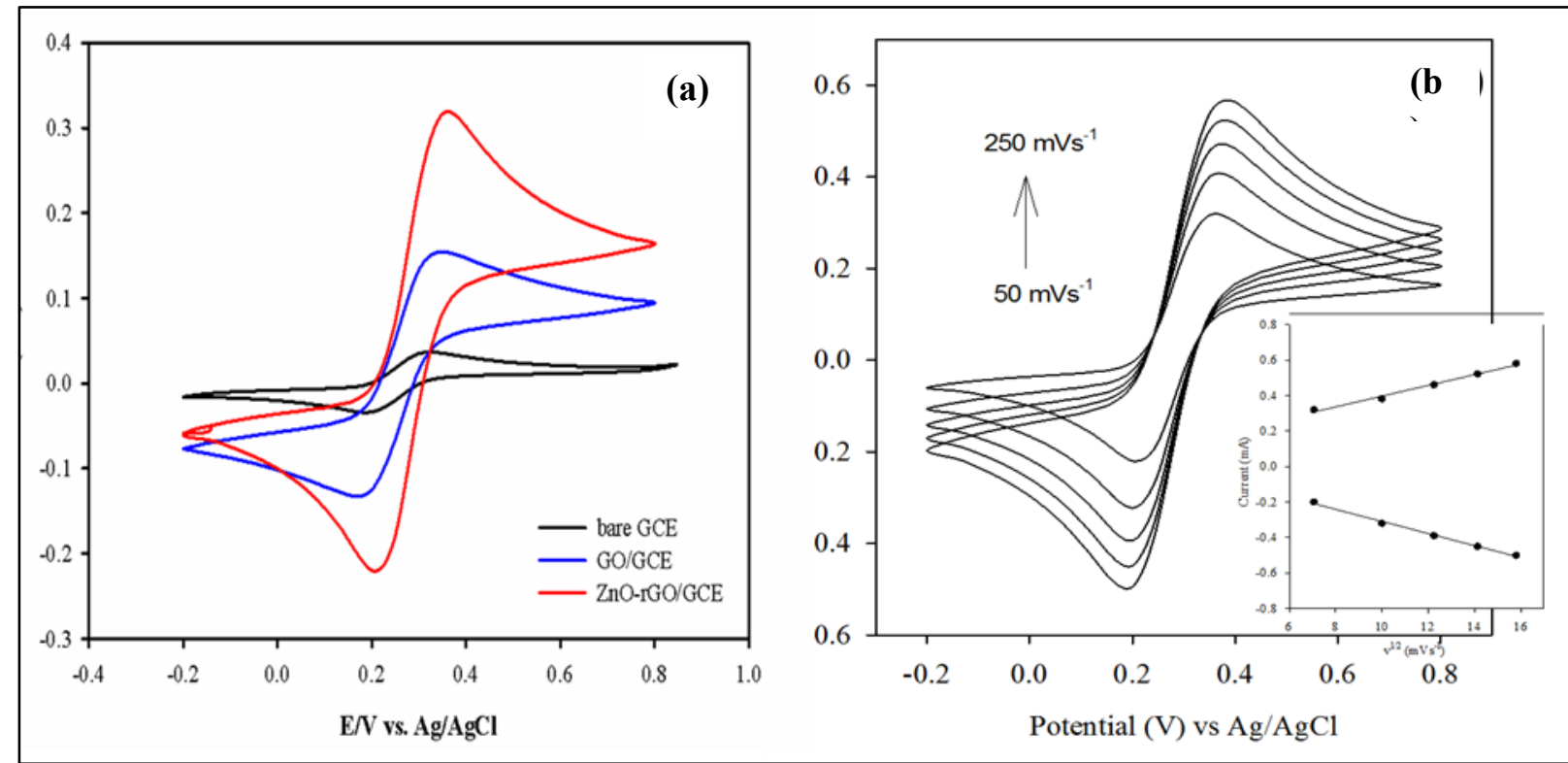

Figure 4. (a) Cyclic voltammograms obtained at the bare GCE, GO and $\mathrm{ZnO} / \mathrm{rGO} / \mathrm{GCE}$ in $0.1 \mathrm{M}$ of $\mathrm{KCl}$ and 0.05 $\mathrm{M}$ of $\mathrm{K}_{4}\left[\mathrm{Fe}(\mathrm{CN})_{6}\right]$ at a scan rate of $250 \mathrm{mVs}^{-1}$ and (b) Cyclic voltammograms of $\mathrm{ZnO} / \mathrm{rGO} / \mathrm{GCE}$ at different scan rate. (Inset: The plot of square root of scan rate vs. current)

The response with smaller peak potential separation on $\mathrm{ZnO} / \mathrm{rGO} / \mathrm{GCE}$ was nearly reversible as a fully reversible system is $\Delta \mathrm{E}_{\mathrm{p}}=59.2 \mathrm{mV}$ at all scan rate, which suggested a rapid electron transfer occurring at the interface of 
$\mathrm{ZnO} / \mathrm{rGO} / \mathrm{GCE}$. Besides, the redox peak currents increased obviously after the $\mathrm{ZnO} / \mathrm{rGO}$ solution was drop-casted on the surface of bare GCE surface, which can be attributed to the synergistic effect of $\mathrm{rGO}$ and $\mathrm{ZnO}$, promoting the electron transfer between the redox probe and the electrode surface.

The improved electrochemical behavior can be attributed to the excellent electrical conductivity of the $\mathrm{ZnO} / \mathrm{rGO}$ present on the electrode surface. The carbon atoms in GO is decorated by oxygen-containing groups, which can expand the interlayer distance of graphene layer but also make the atomic-thick layers became hydrophilic. These properties will result the low electrochemical properties of synthesized GO [12]. Thus, the chemical reduction of GO should be carry out to reduce the oxygen-containing group which anchor on the surface of $\mathrm{GO}$. $\mathrm{Zn} / \mathrm{rGO}$ composite was produced after the GO was treated with $\mathrm{Zn}\left(\mathrm{NO}_{3}\right)_{2}$ as reduce precursors. The conductivity of monolayer graphene mainly relies on carrier transport within the carbon plane. Thus, various functional groups anchored to the plane are the main factor that influencing its conductivity.

The graphene with superior electrical conductivity and unique electron transport property could accelerate the electron transfer rate at the electrode/electrolyte interface. This shows that the electrical conductivity of $\mathrm{ZnO}$ is greatly enhanced the bare electrode. $\mathrm{KCl}$ and $\mathrm{K}_{4}\left[\mathrm{Fe}(\mathrm{CN})_{6}\right]$ was used as the electrolyte to determine the electrochemical behavior for both electrode due to $\mathrm{KCl}$ is the inert supporting electrolyte which ensure that the ionic strength of the solution is high and hence that the electric field is homogeneous and near-zero and is not perturbed by the oxidation or reduction of the analyte concerned. While $\mathrm{K}_{4}\left[\mathrm{Fe}(\mathrm{CN})_{6}\right]$ act as the redox species that present the reduction peak in cyclic voltammogram.

To investigate the reaction kinetics, the influence of scan rates on the electrocatalytic response of $\mathrm{ZnO} / \mathrm{rGO} / \mathrm{GCE}$ in $\mathrm{K}_{4}\left[\mathrm{Fe}(\mathrm{CN})_{6}\right]$ was examined and the results are shown in Figure $4 \mathrm{~b}$. The scan cycles and potential range were standardized at value of $0.10 \mathrm{mM}, 6$ scan cycles, and $-0.2 \mathrm{~V}$ to $0.8 \mathrm{~V}$ respectively. It can be clearly observed that the oxidation peak currents are increased linearly while the oxidation peak potential is shifted positively as the scan rate increasing from $50 \mathrm{mVs}^{-1}$ to $250 \mathrm{mVs}^{-1}$, accompanied with an enlargement of the peak separation. Moreover, the increased of cathodic and anodic peak currents as the scan rate increased from $50 \mathrm{mVs}^{-1}$ to $250 \mathrm{mVs}^{-1}$ attributed that the electro-redox of ferrocyanide ion on $\mathrm{ZnO} / \mathrm{rGO} / \mathrm{GCE}$ is a typical diffusion controlled process [22]. In addition, at higher scan rates, the anode $\left(\mathrm{E}_{\mathrm{pa}}\right)$ and cathode $\left(\mathrm{E}_{\mathrm{pc}}\right)$ peak potential have a linear relationship with the square root of scan rate (Figure $4 \mathrm{~b}$ : Inset). This is due to no stirring process was performed during CV test. Thus, the thickness of diffusion layer is increased as the time passes through and the concentration of ferrocyanide at the electrode surface had further diffused from the bulk solution. The faster the scan rate, the shorter the diffusion layer; hence greater the electron transfer [23]. Besides, the flux to the electrode is smaller at lower scan rate compare with the higher scan rate and the current is directly proportional to flux toward the electrode. Thus, scan rate $50 \mathrm{mVs}^{-1}$ is selected as the optimize scan rate for further electrochemical study of $\mathrm{DA}$ at $\mathrm{ZnO} / \mathrm{rGO} / \mathrm{GCE}$.

\section{Electrocatalytic response of towards the oxidation of dopamine (DA)}

Figure 5a shows the $\mathrm{CV}$ responses obtained for the bare $\mathrm{GCE}$ and $\mathrm{ZnO} / \mathrm{rGO} / \mathrm{GCE}$ in the presence of $0.1 \mathrm{mM}$ DA in $0.1 \mathrm{M}$ PBS by scan rate of $50 \mathrm{mVs}^{-1}$ at $\mathrm{pH}$ 7. At a bare GCE, a well-defined redox peak is observed $347 \mathrm{mV}$ and $243 \mathrm{mV}$ with the anodic current of $3.39 \mu \mathrm{A}$. However, at $\mathrm{ZnO} / \mathrm{rGO} / \mathrm{GCE}$ the oxidation peak current is dramatically increased to $20.0 \mu \mathrm{A}$ which can be attributed to the enhanced electrochemical performance towards the oxidation of DA. This might be contributed from the excellent electrical conductivity of the $\mathrm{ZnO} / \mathrm{rGO}$ presented on the electrode surface that can act as an effective electron promoter for electrocatalytic oxidation of DA. As the voltage increasing from $-0.2 \mathrm{~V}, \mathrm{DA}$ is attracted to the surface of $\mathrm{ZnO} / \mathrm{rGO} / \mathrm{GCE}$. This situation lead the diffusion layer become greater as voltage increase, large amount of DA molecule adsorbed over the electrode surface. 

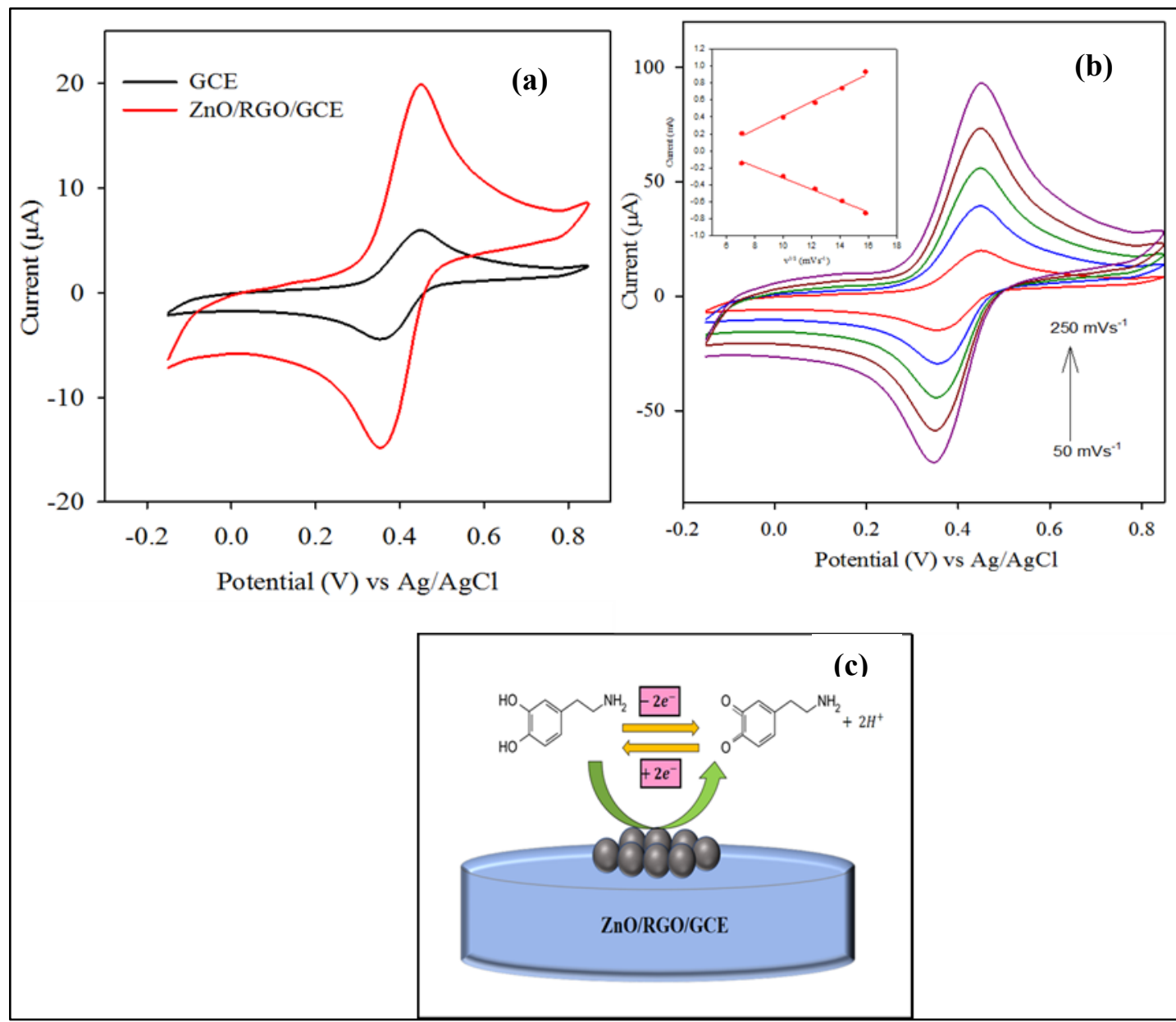

Figure 5. (a) Cyclic voltammograms obtained at the bare $\mathrm{GCE}$ and $\mathrm{ZnO} / \mathrm{rGO} / \mathrm{GCE}$ in $0.1 \mathrm{M}$ of $\mathrm{PBS}$ (pH 7) containing $1.0 \mathrm{mM}$ of DA, (b) Cyclic voltammograms obtained at $\mathrm{ZnO} / \mathrm{rGO} / \mathrm{GCE}$ in $0.1 \mathrm{M}$ of PBS (pH 7) containing $1.0 \mathrm{mM}$ of DA at different scan rate $\left(50,100,150,200\right.$, and $\left.250 \mathrm{mVs}^{-1}\right)$. (Inset: the plot of peak current vs. square root of scan rate) and (c) Electrocatalytic oxidation of dopamine at $\mathrm{ZnO} / \mathrm{rGO} / \mathrm{GCE}$

The effect of potential scan rate was studied on the electrocatalytic properties of the $\mathrm{ZnO} / \mathrm{rGO} / \mathrm{GCE}$ toward oxidation of DA. As can be seen in Figure 5b, increase in scan rate potential, resulted in non-shifted potential value for the catalytic oxidation of DA. This result suggesting a stable kinetic in the reaction between the redox sites of the $\mathrm{ZnO} / \mathrm{rGO} / \mathrm{GCE}$ and DA. The result also shows that anodic and cathodic current increases with increasing of square root of scan rate indicating diffusion process. Redox reaction process of DA occurred at $\mathrm{ZnO} / \mathrm{rGO} / \mathrm{GCE}$ by two electrons transferred (Figure 5c). DA is oxidized during the positive sweep to form dopamine-o-quinone which is reduced back to dopamine in the negative sweep.

\section{Effect of pH}

The electrochemical behaviour of DA is strongly dependent on the $\mathrm{pH}$ value of electrolyte solution. Phosphate buffer solution (PBS) with different $\mathrm{pH}$ value $(\mathrm{pH} 3$ to $\mathrm{pH} 11$ ) at the surface of $\mathrm{ZnO} / \mathrm{rGO} / \mathrm{GCE}$ was prepared to investigate the optimum condition for the best electroactivity of DA standard solution. Figure 6 shows the characterizing of $0.10 \mathrm{mM}$ of DA standard solution in $0.1 \mathrm{M}$ of PBS with different $\mathrm{pH}$ at constant scan cycle (6 scan) and scan rate $\left(50 \mathrm{mVs}^{-1}\right)$ at $\mathrm{ZnO} / \mathrm{rGO} / \mathrm{GCE}$. Cyclic voltammograms obtained with the $\mathrm{ZnO} / \mathrm{rGO} / \mathrm{GCE}$ for electrolyte containing DA in higher $\mathrm{pH}$ condition shows that DA did not couple with the $\mathrm{ZnO} / \mathrm{rGO} / \mathrm{GCE}$ and show 
the lowest current peak compare to others. At $\mathrm{pH} 3$ and 7 the oxidation peak current $\left(I_{p a}\right)$ shows the maximum and obvious current. This indicated that the DA oxidized efficiency in both acidic and neutral condition. In this study, the redox reaction process of DA involves the transfer of two protons and two electrons. This phenomenon indicates that the uptake of electrons is accompanied by the same protons [24]. Therefore, considering the sensitive determination for DA, $0.10 \mathrm{M}$ of PBS (pH 7) can be selected for further electrochemical investigation of DA at $\mathrm{ZnO} / \mathrm{rGO} / \mathrm{GCE}$.

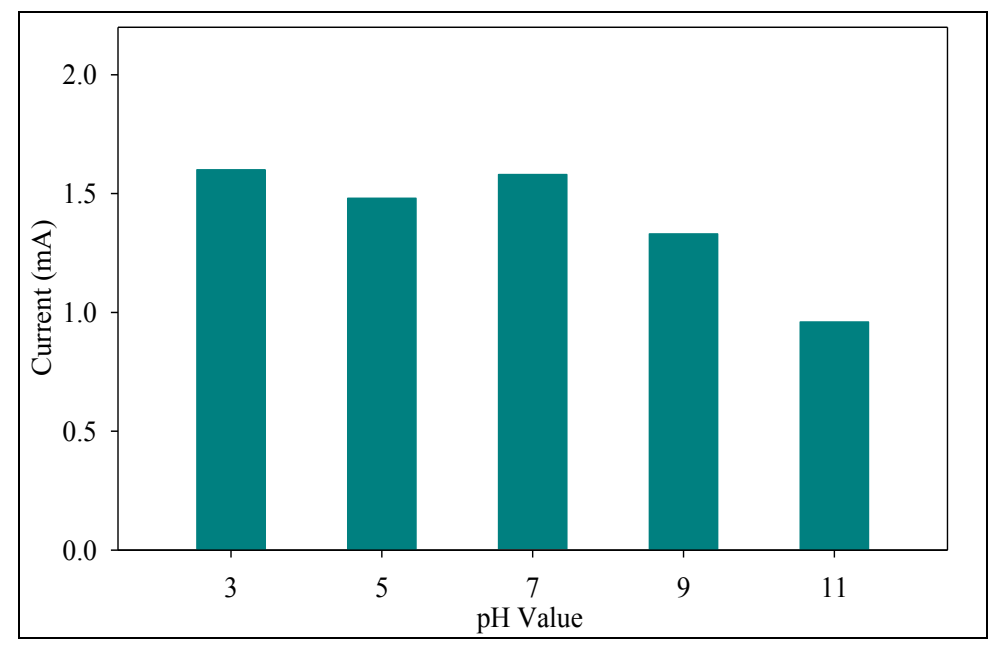

Figure 6. Chart of current $v s$. $\mathrm{pH}$ at the $\mathrm{ZnO} / \mathrm{rGO} / \mathrm{GCE}$ in $0.1 \mathrm{M}$ of PBS with different $\mathrm{pH}$ value (pH 3, $\mathrm{pH} 5, \mathrm{pH} 7$, $\mathrm{pH} 9$ and $\mathrm{pH} 11)$ at scan rate $50 \mathrm{mVs}^{-1}$ which containing $1.0 \mathrm{mM}$ of DA

\section{Conclusion}

The modified electrode $\mathrm{ZnO} / \mathrm{rGO} / \mathrm{GCE}$ composite had been successfully synthesized via a simple, cost-effective and green approach method. The $\mathrm{ZnO} / \mathrm{rGO} / \mathrm{GCE}$ showed significantly improved peaks currents towards the redox reaction of DA compared with the bare GCE. Modified Hummers' method was proposed in this research to synthesized graphene oxide from raw graphite powder. Chemical reduction was carried out to reduce GO to $\mathrm{ZnO} / \mathrm{rGO}$. Chemical reduction was choosing due to the $\mathrm{rGO}$ which synthesize by this method is has a substandard surface area and electrically conductivity. The functional groups that anchor on the surface of graphene layer were characterized by Fourier transform infrared spectroscopy (FTIR). In addition, the morphology of $\mathrm{ZnO} / \mathrm{rGO}$ was physical characterized by X-Ray diffractometer (XRD) and Scanning Electron Microscope (SEM). The FTIR results obtained indicate that the oxygen containing groups were almost reduced when the GO treat with $\mathrm{ZnO} / \mathrm{rGO}$ as reduced precursor. Besides, the results from XRD and SEM proved that the ZnO composite were successfully covered on the graphene layer when the GO was chemical reduced. The $\mathrm{ZnO}$ composite which anchor on the surface of graphene layer will enhance the electrochemical behavior of GCE toward the redox reaction of DA. The $\mathrm{ZnO} / \mathrm{rGO} / \mathrm{GCE}$ displayed excellent electrocatalytic activity towards the DA oxidation. These results attribute that the $\mathrm{ZnO} / \mathrm{rGO} / \mathrm{GCE}$ could be a candidate for clinical, electrochemical and biosensor applications due to its excellent electrical performance.

\section{Acknowledgements}

The authors gratefully acknowledge to Ministry of Education for financial support from the Research Acculturation Grant Scheme (RAGS) RAGS/1/2015/ST0/UMT/03/2, Fundamental Research Grant Scheme (FRGS) FRGS/1/2017/STG01/UMT/02/2 and Central Lab UMT for providing facilities for undertaking this research.

\section{References}

1. Hu, X., Qi, R., Zhu, J., Luo, Y., Jin, J. and Jiang, P. (2014). Preparation and properties of dopamine reduced graphene oxide and its composites of epoxy. Journal of Applied Polymer Science, 131(2): 39754. 
2. Siciliano, C. A., Locke, J. L., Mathews, T. A., Lopez, M. F., Becker, H. C. and Jones, S. R. (2017). Dopamine synthesis in alcohol drinking-prone and -resistant mouse strains. Alcohol, 58: $25-32$.

3. Kim, D., Lee. S. and Piao Y. (2017). Electrochemical determination of dopamine and acetaminophen using activated graphene-nafion modified glassy carbon electrode. Journal of Electroanalytical Chemistry, 794: $221-228$.

4. Quan, D. P., Tuyen, D. P., Lam, T. D., Tram, P. T. N., Binh, N. H. and Viet, P. H. (2011). Electrochemically selective determination of dopamine in the presence of ascorbic and uric acids on the surface of the modified nafion/single wall carbon nanotube/poly(3-methylthiophene) glassy carbon electrodes. Colloids and Surfaces B: Bionterfaces, 88(2): $764-770$.

5. Wilson, G. S. and Johnson, M. A. (2008). In-vivo electrochemistry: What can we learn about living systems? Chemical Review, 108 (7): 2462 - 2481.

6. Lakshmi, D., Bossi, A., Whitcombe, M. J., Chianella, I., Fowler, S. A., Subrahmanyam, S., Piletska, E. V. and Piletsky, S. A. (2009). Electrochemical sensor for catechol and dopamine based on a catalytic molecularly imprinted polymer-conducting polymer hybrid recognition element. Analytical Chemistry, 81(9): 3578 - 3584.

7. Mahshid, S., Li, C., Mahshid, S. S., Askari, M., Dolati, A., Yang, L., Luo, S. and Cai, Q. (2011). Sensitive determination of dopamine in the presence of uric acid and ascorbic acid using $\mathrm{TiO}_{2}$ nanotubes modified with Pd, Pt and Au nanoparticles. Analyst, 136(11): 2322 - 2329.

8. Fang, B., Wang, G., Zhang, W., Li, M. and Kan, X. (2005). Fabrication of $\mathrm{Fe}_{3} \mathrm{O}_{4}$ nanoparticles modified electrode and its application for voltammetric sensing of dopamine. Electroanalysis, 17(9): 744 - 748.

9. Wang, W., Xu, G., Cui, X. T., Sheng, G. and Luo, X. (2014). Enhanced catalytic and dopamine sensing properties of electrochemically reduced conducting polymer nanocomposite doped with pure graphene oxide. Biosensors and Bioelectronics, 58: 153 - 156.

10. Liu, X., Peng, Y., Qu, X., Ai, S., Han, R. and Zhu, X. (2011). Multi-walled carbon nanotubechitosan/poly(amidoamine)/DNA nanocomposite modified gold electrode for determination of dopamine and uric acid under coexistence of ascorbic acid. Journal of Electroanalytical Chemistry, 654 (1-2): 72 - 78.

11. Hernandez, Y., Nicolosi, V., Lotya, M., Blighe, F. M., Sun, Z., De, S., McGovern, I. T., Holland, B., Byrne, M., Gun'ko, Y., Boland, J., Niraj, P., Duesberg, G., Krishnamurti, S., Goodhue, R., Hutchison, J., Scardaci, V., Ferrari, A. C. and Coleman, J. N. (2008). High-yield production of graphene by liquid-phase exfoliation of graphite. Nature Nanotechnology, 3(9): 563 - 568.

12. Shan, C., Tang, H., Wong, T., He, L. and Lee, S-T. (2012). Facile synthesis of a large quantity of graphene by chemical vapor deposition: an advanced catalyst carrier. Advanced Materials, 24(18): 2491 - 2495.

13. Fan, Z. J., Kai, W., Yan, J., Wei, T., Zhi, L. J., Feng, J., Ren, Y. M., Song, L. P. and Wei, F. (2011). Facile synthesis of graphene nanosheets via fe reduction of exfoliated graphite oxide. ACS Nano, 5(1): 191 - 198.

14. Ling, Y. Y., Huang, Q. A., Zhu, M. S., Feng, D. X., Li, X. Z. and Wei, Y. (2013). A facile one-step electrochemical fabrication of reduced graphene oxide-multiwall carbon nanotubes-phospotungstic acid composite for dopamine sensing. Journal of Electroanalytical Chemistry, 693: 9 - 15.

15. Zhang, F., Wang, Z., Zhang, Y., Zheng, Z., Wang, C., Du, Y. and Ye, W. (2012). Simultaneous electrochemical determination of uric acid, xanthine and hypoxanthine based on poly(1-arginine)/graphene composite film modified electrode. Talanta, 93: 320 - 325.

16. Wang, G., Shen, X., Wang, B., Yao, J. and Park, J. (2009). Synthesis and characterization of hydrophilic and organophilic graphene nanosheets. Carbon, 47(5): 1359 - 1364.

17. Cui, X., Fang, X., Zhao, H., Li, Z. and Ren, H. (2017). An electrochemical sensor for dopamine based on polydopamine modified reduced graphene oxide anchored with tin dioxide and gold nanoparticles. Analytical Methods, 36(9): 5322 - 5332.

18. Chang, Z., Zhou, Y., Hao, L., Hao, Y., Zhu, X. and Xu, M. (2017). Simultaneous determination of dopamine and ascorbic acid using $\beta$-cyclodextrin/au nanopaerticles/graphene-modifie electrodes. Analytical Methods, 9(4): 664 - 671.

19. Tang, L., Li, X., Ji, R., Teng, K. S., Tai, G., Ye, J., Wei, C. and Lau, S. P. (2012). Bottom-up synthesis of largescale graphene oxide nanosheets. Journal of Materials Chemistry, 22(12): 24981 - 24982.

20. Babu K. S., Reddy, R., Sujatha, C., Reddy, K. V. and Mallika, A. N. (2013). Synthesis and optical characterization of porous ZnO. Journal of Advanced Ceramic, 2(3): 260 - 265. 
21. Chen, Y. L., Hu, Z. A., Wang, H. W., Zhang, Z, Y., Yang, Y. Y. and Wu, H. Y. (2011). Zinc oxide/reduced graphene oxide composites and electrochemical capacitance enhanced by homogeneous incorporation of reduced graphene oxide sheets in zinc oxide matrix. The Journal of Physical Chemistry, 115(5): 2563 - 2571.

22. Yusoff, F., Aziz, A., Mohamed, N. and Ghani, S. A. (2013). Synthesis and characterizations of BSCF at different $\mathrm{pH}$ as future cathode materials of fuel cells. International Journal of Electrochemical Science, 8(8): 10672 - 10687.

23. Fritea, L., Goff, A. L., Putaux, J. L., Tertis, M., Cristea, C., Sãndulescu, R. and Cosnier, S. (2015). Design of a reduced-graphene-oxide composite electrode from an electropolymerizable graphene aqueous dispersion using a cyclodextrin-pyrrole monomer. Application to dopamine biosensing. Electrochimica Acta, 178: 108 - 112.

24. Avendańo S. C., Angeles, G. A., Silva, M. T. R., Pina, G. R., Romo, M. R. and Pardavě, M. P. (2007). On the electrochemistry of dopamine in aqueous solution. Part 1: The role of [SDS] on the voltammetric behavior of dopamine on a carbon paste electrode. Journal of Electroanalytical Chemistry, 609(1): 17 - 26. 